\title{
Pengaruh Likopen terhadap Kadar Soluble FMS-Like Tyrosine Kinase 1 pada Preeklamsi
}

\author{
Vaulinne Basyir ${ }^{1}$, Prima Nanda Fauziah ${ }^{2}$, Akhmad Yogi Pramatirta ${ }^{3}$, Yanwirasti ${ }^{4}$, Johanes Cornelius Mose ${ }^{3}$, Fadil
} Oenzil $^{4}$

\begin{abstract}
Abstrak
Preeklamsi merupakan penyebab utama morbiditas dan mortalitas baik maternal maupun perinatal. Tujuan: Menganalisis pengaruh pemberian likopen terhadap kadar sFlt-1 secara in vitro pada sel trofoblas model preeklamsi. Metode: Penelitian ini dilakukan secara eksperimental di Laboratorium Genetika Molekuler dan Kultur Sel Fakultas Kedokteran Universitas Padjadjaran selama periode 2017-2018. Sampel serum diperoleh dari RS. Dr. Hasan Sadikin Bandung, sesuai kriteria inklusi dan eksklusi. Kriteria inklusi adalah pasien yang telah didiagnosis preeklamsi berdasarkan pemeriksaan tekanan darah dan protein urin, dan kriteria eksklusi adalag pasien yang tidak datang kontrol atau tidak bisa dihubungi. Penelitian ini terdiri dari dua tahap, pertama ditentukan nilai LD $_{50}$ likopen terhadap sel trofoblas kemudian dijadikan dasar nilai konsentrasi yang akan digunakan, selanjutnya dilakukan pemeriksaan sFIt1 menggunakan metode Elisa pada kultur sel trofoblas kondisi normal dan preeklamsi dengan analisa data menggunakan analisis varians (Anova) dan uji Duncan untuk mengetahui perbedaan antar variabel. Hasil: Nilai $L D_{50}$ adalah $250 \mathrm{ug} / \mathrm{ml}$ dan serial konsentrasi yang digunakan mulai dari 1,953 sampai dengan $125 \mathrm{ug} / \mathrm{ml}$. Didapatkan kadar sFlt-1 menurun secara signifikan $(p \leq 0,05)$ dari 39,5445 menjadi $31,1342 \mathrm{pg} / \mathrm{ml}$ pada sel trofoblas yang diinduksi dengan serum preeklamsi setelah pemberian konsentrasi likopen sebesar 15,625-31,25 ug/ml yang nilainya mendekati keadaan pada sel trofoblas yang diinduksi serum kehamilan normal. Pemberian likopen dapat menurunkan kadar sFlt1 pada sel trofoblas preeklamsi. Simpulan: Likopen dapat merubah kadar sFlt-1 dan perubahannya dipengaruhi oleh konsentrasi dan jenis serum.
\end{abstract}

Kata kunci: likopen, preeklampsi, sFIt-1

\section{Abstract}

Preeclampsia is a major cause of morbidity and maternal and perinatal mortality. Objectives: To analyzed the effect of lycopene to the levels of sFlt-1 in vitro on trophoblast cell respectively induced by normal and preeclampsia serum. Methods: This research was carried out experimentally in the laboratory at Molecular Genetics and Cell Culture Laboratory, Faculty of Medicine Universitas Padjadjaran. Serum samples obtained from Hasan Sadikin Hospital, Bandung in accordance with inclusion and exclusion criteria. The inclusion criteria were patients who have diagnosed with preeclampsia from the blood pressure and proteinuria examination, and the exclusion criteria were patients who did not come to control or can not be contacted. First determined LD50 values of lycopene against trophoblast cell and then used as the basis value concentration. Further, examinations of sFlt-1 with Elisa method on trophoblast cell normal conditions and preeclampsia with data analysis using analysis of variance (Anova) and Duncan test to determine differences between variables. Results: The LD50 value was $250 \mathrm{ug} / \mathrm{ml}$ and serial concentrations used ranging from 1,953 until $125 \mathrm{ug} / \mathrm{ml}$. Obtained sFlt-1 levels decreased significantly $(p \leq 0,05)$ from 39,5445 to $31,1342 \mathrm{pg} / \mathrm{ml}$ the trophoblast cell preeclampsia induced by serum concentration after administration lycopene of $15,625-31,25 \mathrm{ug} / \mathrm{ml}$ whose value approaches the state of the trophoblast cell induced serum of normal pregnancy. Conclusion: Lycopene can changes the levels of sFlt-1. Its influenced by lycopene concentration and the type of serum.

Keywords: lycopene, preeclampsia, sFlt-1 
Affiliasi penulis: ${ }^{1}$ Bagian Obstetri dan Ginekologi, Fakultas Kedokteran, Universitas Andalas, Padang, Indonesia. ${ }^{2}$ Prodi Analis Kesehatan, Fakultas Kesehatan, Universitas Mohammad Husni Thamrin, Jakarta, Indonesia. ${ }^{3}$ Departemen Obstetri dan Ginekologi, Fakultas Kedokteran, Universitas Padjadjaran, Bandung, Indonesia. ${ }^{4}$ Fakultas Kedokteran, Universitas Andalas, Padang, Indonesia. Korespondensi: Vaulinne Basyir, Email: vaulinne@gmail.com Telp: 08126618805. Alamat: Jalan Perintis Kemerdekaan No.94, 25127, Padang, Indonesia.

\section{PENDAHULUAN}

Preeklamsi masih merupakan penyebab utama morbiditas dan mortalitas baik maternal maupun perinatal. Angka kejadian preeklamsi sampai saat ini masih tinggi dan penatalaksanaan belum optimal, hal ini disebabkan karena etiologi dan patofisiologi preeklamsi belum diketahui secara pasti. ${ }^{1,2}$

Penyakit ini terjadi karena faktor genetik, faktor imunologi, penyakit pembuluh darah dan keadaan dimana jumlah trofoblas berlebih yang dapat mengakibatkan ketidakmampuan invasi trofoblas terhadap arteri spiralis pada awal trimester pertama. Hal ini menyebabkan arteri spiralis tidak dapat berdilatasi sempurna dan terjadi ketidak sempurnaan lapisan endotel serta lapisan otot pembuluh darah, menghasilkan diameter pembuluh darah yang lebih kecil dan akan berakibat menurunnya aliran darah, sehingga terjadi iskemik plasenta. Keadaan ini berlanjut menjadi stress oksidasi, peningkatan radikal bebas, disfungsi endotel, agregasi trombosit dan hipoksia yang dapat terjadi di berbagai organ ibu. ${ }^{3-5}$

Iskemik plasenta menyebabkan peningkatan placental soluble fms-like tyrosine kinase-1 (sFlt-1), yang merupakan antiangiogenik yang dihasilkan oleh sel plasenta yang mengalami hipoksia. sFlt-1 dianggap sebagai salah satu faktor etiologi terjadinya kerusakan endotel pada preeklamsia karena peningkatan kadar sFlt-1 dapat merubah integritas endotel pembuluh darah. Salah satu akibatnya adalah terjadi kerusakan sawar darah otak yang menyebabkan edema otak dan hepar, dan juga hipertensi serta proteinuria yang sering ditemukan pada pasien preeklamsi. ${ }^{5-7}$

Hasil penelitian menunjukkan bahwa perubahan sFlt-1 mulai dari awal kehamilan minggu ke-10 sampai 11 dapat digunakan sebagai waktu yang tepat untuk mempelajari terjadinya preeklamsi di kehamilan lanjut.
Kadar sFIt-1 antagonis terhadap PIGF, sehingga perubahan kadar sFIt-1 dan PIGF akan menyebabkan ketidakseimbangan proses angiogenesis yang diikuti dengan kegagalan invasi trofoblas dan remodelling arteri spiralis yang berakhir hipoksia. ${ }^{8,9}$

Pada penderita preeklamsi akan terjadi perubahan endotel pembuluh darah dengan menurunkan sintesis fosforilasi oksida nitrit pada sel endotel oleh karena terjadi peningkatan sFlt-1. Penurunan sintesis fosforilasi oksida ini akan merubah bioavaibility oksida nitrit (NO) yang dihasilkan oleh endotel dan pada akhirnya akan terjadi perubahan homeostasis kardiovaskular. ${ }^{10}$ Peningkatan radikal bebas pada pasien preeklamsi berasosiasi dengan penurunan antioksidan di dalam sel. Antioksidan ini berperan dalam menurunkan stres oksidatif pada sel. $^{8,10}$

Antioksidan merupakan suatu senyawa yang dapat meredam dampak negatif oksidan, secara kimia dapat diartikan sebagai senyawa pemberi elektron. Kerja dari antioksidan yaitu melalui mekanisme pencegah dan pemutus reaksi rantai. Antioksidan telah banyak ditemukan di alam dan telah diteliti manfaatnya terhadap beberapa penyakit. Beberapa peneliti telah membuktikan bahwa antioksidan dapat menurunkan risiko preeklamsi seperti pemberian vitamin $\mathrm{E}$, vitamin $\mathrm{C}$ dan likopen pada ibu hamil dapat mencegah preeklamsi. ${ }^{11,12}$

Likopen merupakan antioksidan kuat karena mempunyai ikatan konjugasi ganda. Likopen banyak terkandung pada buah tomat. Struktur kimia likopen merupakan suatu senyawa yang kaya elektro dan tidak stabil sehingga mudah bereaksi dengan oksigen dan peroksida serta senyawa radikal bebas. ${ }^{13,14}$ Manfaat likopen telah banyak dibuktikan untuk pencegahan kanker prostat, kanker paru akibat merokok, penderita katarak, kelainan jantung, endometriosis, osteoporosis ${ }^{15}$, sehingga peneliti tertarik mengetahui pengaruh peran likopen dalam mencegah terjadinya preeklamsi.

\section{METODE}

Penelitian ini adalah eksperimental murni dengan desain post-test only control group design yang dilakukan Bagian SMF Obstetri dan Ginekologi RSUP 
dr. Hasan Sadikin Bandung untuk pengambilan sel trofoblas dari ibu melahirkan dan serum dari ibu hamil normal dan preeklamsi, Laboratorium Kultur Sel Fakultas Kedokteran Universitas Padjadjaran untuk melakukan kultur sel trofoblas dan penentuan LC50, serta Laboratorium Genetika Molekuler untuk melakukan pemeriksaan sFlt-1. Penelitian ini telah disetujui oleh Komite Etik Fakultas Kedokteran Universitas Andalas Padang (Surat Keterangan Lolos Kaji Etik No. 083/KEP/FK/2015).

Kriteria inklusi untuk penelitian ini dibagi menjadi dua kelompok, yaitu kelompok hamil normal dan preeklamsi. Kelompok hamil normal meliputi: pasien hamil tunggal dengan janin hidup hasil pemeriksaan ultrasonografi (USG), usia kehamilan 34-42 minggu berdasarkan Hari Pertama Haid Terakhir (HPHT), tekanan darah normal dan proteinuri negatif. Kelompok preeklamsi meliputi: pasien hamil tunggal dengan janin hidup hasil pemeriksaan ultrasonografi (USG), usia kehamilan 34-42 minggu berdasarkan HPHT, tekanan darah $\geq 160 / 110 \mathrm{mmHg}$, dan proteinuri positif.

Kriteria eksklusi pada penelitian ini adalah terdapat tanda dan gejala infeksi sistemik, kehamilan yang telah didiagnosis memiliki komplikasi medis, mempunyai riwayat kelainan kardiovaskuler sebelumnya, berdasarkan anamnesa sebelumnya atau rekam medis, dan tidak bersedia diambil darahnya.

Likopen yang digunakan adalah Likopen SIGMA ALDRICH L9879 (>90\%, tomat, $1 \mathrm{mg}$ per-ampul). Kadar sFlt-1 diperiksa menggunakan metode Enzyme link-immunosorrbent assay (Elisa) Mybiosource Lot. \#32257786. Sel trofoblas yang digunakan dari penelitian Pramatirta et al. ${ }^{16}$

Diambil total satu sampel darah wanita dengan kehamilan preeklamsi dan satu sampel darah wanita dengan kehamilan normal (tanpa preeklamsi) sebanyak $20 \mathrm{cc}$ untuk mendapatkan $10 \mathrm{cc}$ serum per sampel. Pengambilan sampel dilakukan melalui vena tangan bagian kanan atau kiri pasien. Sebelum pengambilan sampel, wanita hamil yang datang untuk pemeriksaan kehamilan di RS dr. Hasan Sadikin Bandung harus memenuhi kriteria inklusi dan eksklusi serta bersedia untuk diambil darahnya dengan mengisi informed consent.
Penelitian ini menggunakan dua tahap penelitian. Tahap pertama adalah penentuan aktivitas antioksidan (lethal concentration 50/ LC50) dengan Brine Shrimp Method yang termodifikasi. ${ }^{19}$ LC50 dari likopen terhadap sel trofoblas dengan menggunakan DMEM + DPPH (2,2-difenil-1-picrylhydrazyl). Parameter yang diamati adalah mencari konsentrasi LC50 dari aktivitas antioksidan likopen SIGMA ALDRICH L9879 (>90\%, tomat, $1 \mathrm{mg}$ per-ampul) pada sel trofoblas. Tahap kedua adalah kultur sel trofoblas yang ditambahkan dengan serum maternal penderita preeklamsi yang dibandingkan dengan serum maternal normal setelah diinkubasi dengan berbagai waktu kontak serum, untuk kemudian diberikan perlakuan dengan pemberian likopen. Parameter yang diamati adalah kadar sFlt-1.

Analisis data menggunakan one-way ANOVA dilanjutkan dengan uji Bonferroni dan Duncan untuk mengetahui perbedaan antar variabel pada masingmasing perlakuan. Semua data penelitian dianalisis secara komputerisasi.

\section{HASIL}

Dalam pengujian aktivitas antioksidan LC50 dari sampel likopen terhadap kultur sel trofoblas menggunakan pelarut Dimetil sulfoksida (DMSO). Persentase penghambatan, yaitu nilai absorbansi yang ditunjukkan oleh ELISA microplate reader BIO RAD $680 \mathrm{XR}$, digunakan sebagai standar untuk menghitung nilai LC50 sampel likopen terhadap sel trofoblas.

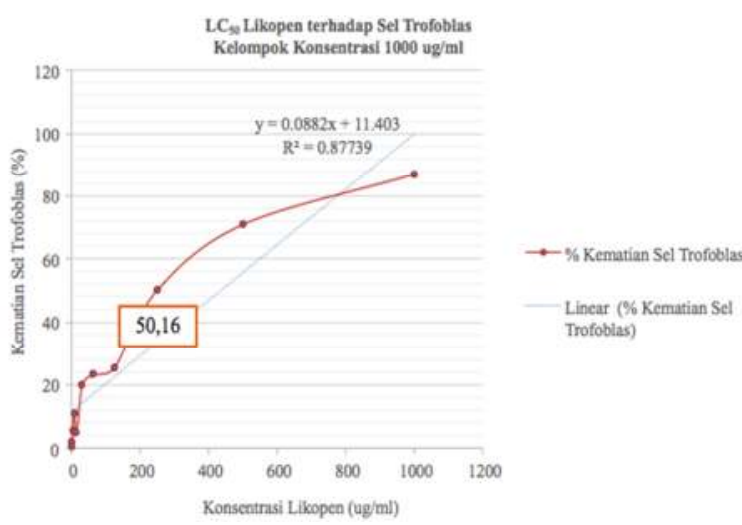

Gambar 1. LC50 likopen terhadap sel trofoblas

Dalam penelitian ini sampel likopen dibagi menjadi 2 serial dosis yaitu kelompok $100 \mu \mathrm{g} / \mathrm{ml}$ dan 
$1000 \mu \mathrm{g} / \mathrm{ml}$, dengan masing-masing kelompok serial dosis terdiri dari 10 kelipatan dosis. Hasil perhitungan LC50 ditunjukkan pada Gambar 1. Pengukuran untuk likopen dilakukan dengan pengulangan sebanyak tiga kali, diperoleh LC50 untuk likopen pada konsentrasi $250 \mathrm{ug} / \mathrm{ml}$ yaitu dengan nilai prosentase kematian sebesar 50,16\% (hasil perhitungan terdapat pada Lampiran 3) dan pada nilai kosentrasi $125 \mathrm{ug} / \mathrm{ml}$ nilai prosentase kematian sebesar $<25,50 \%$. Penentuan aktivitas likopen ditentukan dengan melihat kematian $50 \%$ (LC50) dari sel trofoblas, yaitu nilai LC50 lebih kecil dari $250 \mathrm{ug} / \mathrm{ml}$ berarti memiliki aktivitas nontoksisitas terhadap sel (125 ug/ml).

Analisis Anova dilakukan untuk mengetahui pengaruh berbagai konsentrasi likopen dan serum yang digunakan terhadap kadar sFlt-1 pada lini sel trofoblas. Pengujian statistik untuk mengetahui pengaruh berbagai konsentrasi likopen dan serum yang digunakan terhadap kadar sFlt-1. Variabel tergantung, yaitu kadar sFlt-1 yang diujikan terhadap 2 variabel bebas, yaitu konsentrasi likopen (0-125 ug/ml) dan dua jenis serum yang digunakan yaitu serum normal dan serum preeklamsi yang ditunjukkan pada Gambar 2 dan 3.

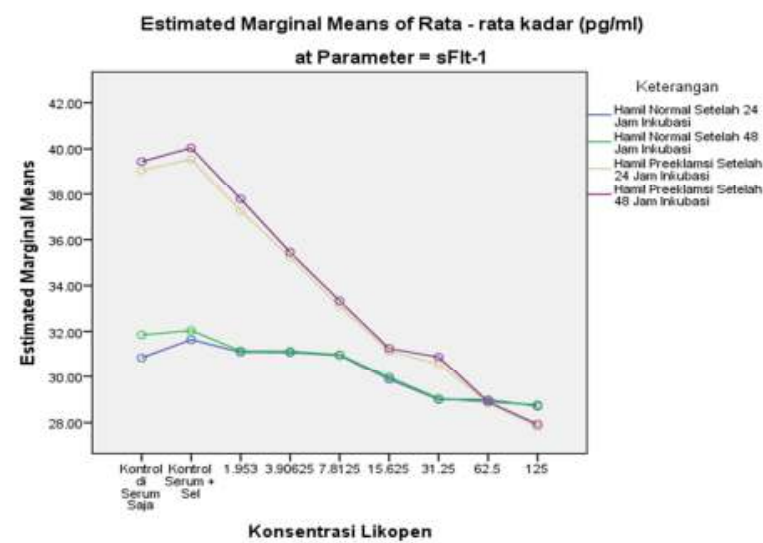

Gambar 2. Perbandingan kadar sFlt-1 pada sel trofoblas perlakuan berdasarkan lamanya waktu inkubasi setelah pemberian berbagai konsentrasi likopen.

Gambar 2 menunjukkan bahwa terdapat perbedaan kadar sFlt-1 yang dipengaruhi oleh jenis serum yang digunakan. Pada sel trofoblas yang diinduksi serum preeklamsi menunjukkan kadar sFlt-1 yang tinggi dibandingkan normal. Semakin besar konsentrasi likopen maka semakin rendah kadar sFIt-1 pada sel trofoblas yang diinduksi serum preeklamsi. Kadar dari sFlt-1 pada sel trofoblas yang diinduksi serum preeklamsi dengan pemberian likopen mendekati kadar sFlt-1 pada sel trofoblas yang diinduksi serum normal tanpa perlakuan.

Pada Gambar 2 terlihat bahwa penurunan terbesar terjadi setelah sel dalam perlakuan normal maupun preeklamsi diinkubasi selama 24 jam. Hal ini dikarenakan sel trofoblas membutuhkan waktu untuk melakukan kontak dengan senyawa yang diberikan ke dalam sel hingga mampu menurunkan sFlt-1. Gambar 2 menunjukkan adanya penurunan kadar sFlt-1 pada sel trofoblas setelah diinkubasi selama 24-48 jam. Perbedaan ini sangat signifikan berdasarkan uji lanjutan Bonferroni dengan nilai $\mathrm{p}<0,05$ seperti ditunjukkan pada Tabel 1.

Tabel 1. Perbandingan kadar sFlt-1 dari berbagai jenis serum dan konsentrasi likopen

\begin{tabular}{|c|c|c|c|c|c|c|c|c|}
\hline & \multirow[b]{2}{*}{ Serum+sel } & \multicolumn{7}{|c|}{ Kadar Likopen (ug/ml) } \\
\hline & & 1.95 & 3.91 & 7.81 & 15.63 & 31.25 & 62.5 & 125 \\
\hline & $\mathrm{p}$ & $\mathrm{p}$ & $\mathrm{p}$ & $\mathrm{p}$ & $\mathrm{p}$ & $\mathrm{p}$ & p & $\mathrm{p}$ \\
\hline $\begin{array}{l}\text { sFLT1 Hamil } \\
\text { normal } 24 \text { jam }\end{array}$ & 0.00 & 0.00 & 0.00 & 0.00 & 0.00 & 0.00 & 0.00 & 0.00 \\
\hline $\begin{array}{l}\text { sFLT1 Hamil } \\
\text { normal } 48 \text { jam } \\
\text { sFLTI }\end{array}$ & 0.00 & 0.00 & 0.00 & 0.00 & 0.00 & 0.00 & 0.00 & 0.00 \\
\hline $\begin{array}{l}\text { Preeklampsia } \\
24 \text { jam } \\
\text { sFLTI }\end{array}$ & 0.00 & 0.00 & 0.00 & 0.00 & 0.00 & 0.00 & 0.00 & 0.00 \\
\hline $\begin{array}{l}\text { Preeklampsia } \\
48 \text { jam }\end{array}$ & 0.00 & 0.00 & 0.00 & 0.00 & 0.00 & 0.00 & 0.00 & 0.00 \\
\hline
\end{tabular}

Gambar 3 dan Tabel 1 menunjukkan hubungan antara pengaruh pemberian berbagai konsentrasi likopen, jenis serum dan lamanya waktu inkubasi terhadap kadar sFlt-1. Pada Gambar 3 dan Tabel 1 terlihat adanya penurunan sFlt-1 pada setiap perlakuan.

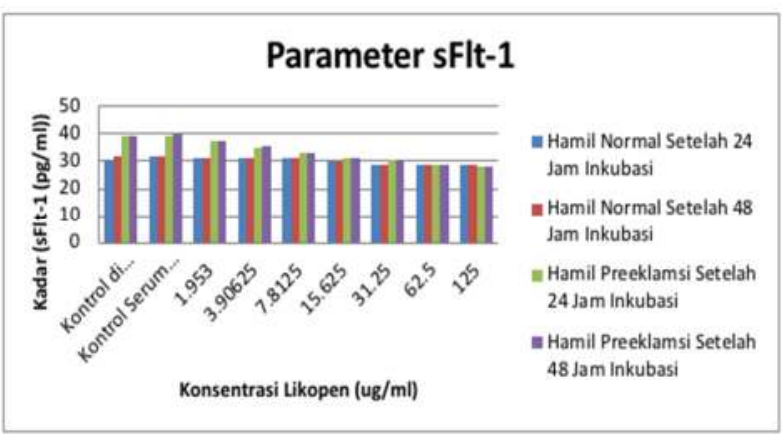

Gambar 3. Kadar sFlt-1 berdasarkan jenis serum, besar konsentrasi likopen dan waktu inkubasi 
Pada Gambar 3 dan Tabel 1 ditunjukkan bahwa kadar sFlt-1 pada sel trofoblas yang diinduksi serum ibu hamil preeklamsi mengalami penurunan setelah diinkubasi selama 24 jam, sedangkan setelah diinkubasi 48 jam, kadarnya lebih menurun dari $40,0344 \mathrm{pg} / \mathrm{ml}$ menjadi $31,2564 \mathrm{pg} / \mathrm{ml}$. Penurunan kadar sFlt-1 pada sel trofoblas yang diinduksi serum preeklamsi tersebut mendekati kadar sel trofoblas yang diinduksi serum hamil normal setelah pemberian konsentrasi likopen 15,625 ug/ml. Oleh karena itu, konsentrasi likopen yang diduga efektif dalam menurunkan kadar sFlt-1 adalah 15,625 ug/ml dan hasil bermakna dengan nilai $p<0,05$.

\section{PEMBAHASAN}

Pada penderita preeklamsi terjadi perubahan proses angiogenesis saat invasi pembuluh darah dari trofoblas ekstravillous ke pembuluh darah uterus dan akan menyebabkan tidak terjadinya penurunan tahanan vaskular plasenta serta akan berakibat buruk terhadap suplai oksigen plasenta karena diameter pembuluh darah akan mengecil, terjadi iskemik serta dapat menyebabkan kerusakan villous trofoblas (kerusakan sel). ${ }^{8}$

Perubahan keseimbangan angiogenesis pada penderita preeklamsi dapat diamati dengan diproduksi sFlt-1 secara berlebih. Soluble fms-like tyrosine kinase-1 merupakan suatu protein yang diekspresikan oleh plasenta sebagai respon terhadap hipoksia. Ketika terjadi hipoksia, maka yang akan terekspresikan pertama kali adalah sFlt-1 jauh sebelum munculnya gejala klinis preeklamsi yaitu hipertensi dan proteinuria. $^{17}$ Peningkatan ekspresi sFlt-1 akan diikuti dengan peningkatan malondialdehid (MDA) yang akan memperburuk keadaan pada penderita preeklamsi dan akan menyebabkan stres oksidatif semakin berat. ${ }^{8,16}$

Peningkatan kadar sFlt-1 akan ditemukan pada ibu dengan preeklamsi, namun juga dapat ditemukan pada ibu tanpa gejala klinis preeklamsi dan bila hal ini terjadi menurut teori ibu tersebut akan mengalami preklamsi dalam beberapa minggu ke depan. Hasil studi pada binatang, yaitu sFlt-1 yang diberikan secara parentral meningkatkan tekanan darah, proteinuria dan endoteliosis gromerulus dan hal ini serupa dengan gejala klinis preeklamsi. Untuk terjadinya kerusakan endotel glomerulus, tidak hanya dengan pemberian sFlt-1 namun juga dengan menurunkan kadar VEGF. ${ }^{18,19}$

Pada penderita preeklamsi, sFlt-1 akan menyebabkan perubahan endotel pembuluh darah dengan cara menduduki tempat untuk reseptor PIGF sehingga menyebabkan penurunan sintesis fosforilasi oksida nitrit pada sel endotel. ${ }^{20}$ Terjadi penurunan sintesis fosforilasi oksida ini akan merubah bioavaibility oksida nitrit yang dihasilkan oleh endotel dan pada akhirnya akan terjadi perubahan homeostasis kardiovaskular yang ditemukan pada penderita preeklamsi. ${ }^{8,16}$ Peningkatan ekspresi sFlt-1, justru memicu degradasi Glial Cell Missing 1 (GCM1) yang berakibat pada penurunan produksi PIGF dan metal-responsive transcription factor (MTF-1).

Hasil pengukuran didapatkan likopen memiliki aktivitas antiangiogenesis terhadap sel trofoblas baik yang diinduksi serum normal maupun serum preeklamsi. Hasil penelitian menunjukkan adanya penurunan kadar sFlt-1 pada sel trofoblas yang diinduksi serum preeklamsi dan kadarnya mendekati kadar sFlt-1 pada sel trofoblas yang diinduksi serum normal tanpa penambahan likopen.

\section{SIMPULAN}

Terdapat pengaruh pemberian likopen 15,625 $\mu \mathrm{g} / \mathrm{ml}$ terhadap kadar sFlt-1. Pengaruh perubahan kadar sFlt-1 oleh likopen dipengaruhi oleh konsentrasi dan jenis serum.

\section{KONFLIK KEPENTINGAN}

Tidak ada konflik kepentingan

\section{UCAPAN TERIMA KASIH}

Terima kasih kepada Bagian SMF Obstetri dan Ginekologi RSUP dr. Hasan Sadikin Bandung dan Laboratorium Kultur Sel dan Genetika Molekuler Fakultas Kedokteran Universitas Padjadjaran, serta kepada semua pihak yang telah memberikan motivasi, bimbingan, dan bantuan kepada penulis dalam menyelesaikan tulisan ini. 


\section{DAFTAR PUSTAKA}

1. Antartani R, Ashok K. Effect of lycopene in prevention of preeclampsia in high risk pregnant women. J Turkish-German Gynecol Assoc. 2011; 12:35-8.

2. Agarwal A, Sekhon LH. The role of antioxidant therapy in the treatment of male infertility. Hum Fertility. 2010;13(4):217-25.

3. Bell MJ, Robert JM, Faunds SA, Jeyabalan A, Terhorst L, Conley YP. Variation in endoglin pathway genes is associated with preclampsia: a case-control candidate gene association study. BMC Pregn Childbirth. 2013;13:82-94.

4. Cynthia GB, Ambika P, Eliza CM, Amelia KB Jason DW, Zainab S, Mary ED, Alexander MF. Preeclampsia outcomes at delivery and race. Journal of Maternal-Fetal and Neonatal Medicine. 2020;33:21:3619-26.

5. Gurnadi JI, Johannes M, Budi H, Prima NF, Akhmad YP. Correlation between fms-like tyrosine kinase-1(sflt-1) cell-free messenger RNA expression and fms-like tyrosine kinase1(sflt-1) protein level in severe preeclampsia and normal pregnancy. International Journal of Integrated Health Sciences (IJIHS). 2015;3(2):66-71.

6. Foo FL, Mahendru AA, Masini G, Fraser A, Cacciatore S, Maclntyre DA, et al. Association between prepregnancy cardiovascular function and subsequent preeclampsia or fetal growth restriction. Hypertension. 2018; 72:442-50.

7. Garrett N, Pombo J, Umpierrez M, Clark JE, Simmons M, Girardi G. Pravastatin therapy during preeclampsia prevents long-term adverse health effects in mice. JCl Insight. 2018; 3:e120147.

8. Gunardi JI, Mose J, Mieke HS, Anita DA, Prima NF, Triyuli. Effects of papua ant nests (Myrmecodia pendens) on level of sFlt-1, PIGF, MDA and NO in preeclampsia-induced HUVEC cell line. International Journal of PharmTech Research. 2016;9(6):424-35.

9. Liu Z, Afink GB, ten Dijke Peter. Soluble fms-like tyrosine kinase 1 and soluble endoglin are elevated circulating anti-angiogenic factor in preeclampsia. Int J Women Cardiovascular Health. 2012;2:358-67.
10. Gajendragadkar PR, Hubsch A, Maki-Petaja KM, Serg M, Wilkinson IB, Cheriyan J. Effects of oral lycopene supplementation on vascular function in patients with cardiovascular disease and healthy volunteers: A randomised controlled trial. PLoS One. 2014;9: e99070.

11. Kim JY, Paik JK, Kim OY, Park HW, Lee JH, Jang $\mathrm{Y}$, Lee JH. Effects of lycopene supplementation on oxidative stress and markers of endothelial function in healthy men. Atherosclerosis. 2011;215:189-95.

12. Yang PM, Chen $\mathrm{HZ}$, Huang YT, Hsieh CW, Wung BS. Lycopene inhibits NF-kappaB activation and adhesion molecule expression through Nrf2mediated heme oxygenase-1 in endothelial cells. Int. J. Mol. Med. 2017;39:1533-40.

13. Gupta S, Jawanda MK, Arora V, Mehta N, Yadav $\mathrm{V}$. Role of lycopene in preventing oral diseases as a nonsurgical aid of treatment. Int. J. Prev. Med. 2015;6: 70.

14. Chen $\mathrm{P}, \mathrm{Xu} \mathrm{S}, \mathrm{Qu}$ J. Lycopene protects keratinocytes against UVB radiation-induced carcinogenesis via negative regulation of FOXO3a through the mtorc2/akt signaling pathway. J. Cell Biochem. 2018;119:366-77.

15. Shih CM, Hsieh CK, Chien-Yu H, Chun-Yao H. Lycopene inhibit imq-induced psoriasis-like inflammation by inhibiting ICAM-1 production in mice. Polymers. 2020;12:1-10.

16. Pramatirta AY, Bremmy L, Prima NF, Anita DA, Sofie RK, Debbie SR, Ani MM, Erlina W. Effects of low dose aspirin on caspase 3, TNF- $\alpha$ and apoptotic index levels in preclampsia maternal serum-induced placental trophoblast cell line in vitro. International Journal of PharmTech Research. 2016;9(10):1-6.

17. Vijayalakshmi, Ambareesha K, Kayalvizhi E, Qairunnisa S, Revathi M, Chandrasekhar M. Effect of antioxidants in preeclampsia women at increased risk. International Journal of Medical Research and Health Sciences. 2013;2(2):17781.

18. Sharma JB, Kumar A, Malhotra M, Arora R, Prasad S, Batra S. Effect of lycopene on preeclampsia and intra-uterine growth retradation in 
primigravidas. Int J Gynaecol Obstet. 2003; 81 (3):257-62.

19. Yeni CM, Fauziah PN, Ani MM, Rovina $R$, Johannes M. Effect of curcumin on sFlt-1 and PIGF concentration in preeclampsia induced HUVEC cell line. Sys Rev Pharm. 2020; 11 (11): 1247-51.
20. Christanto DR, Mose JC, Teti Y, Muhammad BB, Yekti AP, Prima NF. The role of black rice bran (Oryza sativa L. "Sembada Hitam") on levels of malondialdehyde in induction human umbilical vein endothelial cell serum preeclampsia. Open Journal of Obstetrics and Gynecology. 2020;10:1686-92. 